Hegel and Metaphysics 


\section{Hegel-Jahrbuch Sonderband}

Herausgegeben von

Andreas Arndt, Myriam Gerhard und Jure Zovko

\section{Band 7}




\section{Hegel and Metaphysics}

On Logic and Ontology in the System

Edited by

Allegra de Laurentiis

With the collaboration of

Soren Whited 
ISBN 978-3-11-042723-3

e-ISBN (PDF) 978-3-11-042444-7

e-ISBN (EPUB) 978-3-11-042463-8

ISSN 2199-8167

\section{Library of Congress Cataloging-in-Publication Data}

A CIP catalog record for this book has been applied for at the Library of Congress.

\section{Bibliographic information published by the Deutsche Nationalbibliothek}

The Deutsche Nationalbibliothek lists this publication in the Deutsche Nationalbibliografie; detailed bibliographic data are available on the Internet at http://dnb.dnb.de.

(C) 2016 Walter de Gruyter GmbH, Berlin/Boston

Printing and binding: Hubert \& Co GmbH \& Co. KG, Göttingen

(2) Printed on acid-free paper

Printed in Germany

www.degruyter.com 